\title{
"Uma xícara de chá" - um conto de Hjalmar Söderberg
}

"Uma xícara de chá" é uma das vinte breves narrativas que compõem o volume Historietter, escrito pelo sueco Hjalmar Söderberg e publicado em Estocolmo em 1898. O livro despertou o entusiasmo de certas rodas literárias logo após o lançamento, e o poeta e crítico Oscar Levertin chegou a afirmar que "poucas vezes se veem motivos puramente anedóticos transformados com tanto requinte em pequenas verdades e ensinamentos de vida como nessas histórias" e a declarar Söderberg "o homem da palavra bem-escolhida, mas necessária".

A exemplo de outras narrativas presentes em Historietter, "Uma xícara de chá" tem um estilo sóbrio e despido de adornos. O interesse despertado pela história reside em boa parte nessa precisão do estilo, na agudeza das observações feitas pelo narrador, na espirituosidade dos implícitos e nas desventuras vividas por um tipo com inclinações artísticas que se vê em uma situação inusitada - um mote recorrente em outras narrativas presentes no volume em discussão.

Além de crítico, jornalista, dramaturgo e romancista, Hjalmar Söderberg foi também tradutor, e verteu para o sueco obras de Anatole France, Jens Peter Jacobsen, Heinrich Heine, Alfred de Musset e Guy de Maupassant.

A obra mais conhecida que Söderberg legou para a posteridade foi o romance em forma de diário Doktor Glas, escrito em 1905 e traduzido para diversos idiomas.

Uma vez que ele permanece inédito no Brasil, pareceu-me oportuno aproveitar a recente entrada de sua obra em domínio público e publicar algumas traduções esparsas dessas pequenas obras-primas. Os contos "O desenho a nanquim" e "Vox populi" foram publicados em tradução minha na edição P da revista Arte 
e Letra: Estórias, enquanto "Spleen", "A alcachofra" e "Um cachorro sem dono" saíram na edição no 5 da (N. T.) - Revista literária em tradução.

Recomendo a leitura de todos os contos mencionados para qualquer leitor que se entusiasme com "Uma xícara de chá".

Guilherme da Silva Braga

Dublin, 25 de janeiro de 2013

\section{En kopp te}

Hjalmar Söderberg

Det sägs, att man i England kan riskera en god del av sitt sociala anseende genom att dricka brännvin eller därmed jämförliga drycker offentligt. Nå, vart land har sina seder. Jag råkade i går afton tämligen illa ut med anledning av att jag ville dricka en kopp te på kafé ... ja, det kan ju vara likgiltigt vad det var för ett kafé.

Saken är den, att jag för närvarande är sysselsatt med att lägga sista handen vid en roman i två delar, i vilken jag kommer att avslöja humbugen i hela det moderna samhällslivet. Det är bara sista kapitlet som fattas, och jag hade just föresatt mig att skriva det igår. Jag steg alltså upp klockan åtta på morgonen, satte mig brännande av diktarefeber vid skrivbordet i bara skjortan och började: "Oktoberskymningen bredde sig allt tätare över staden, medan höstregnet..." Längre hade jag icke hunnit, då det ringde i min telefon. Det var en av mina vänner, som ville låna pengar - en bagatell, ett par hundra kronor - men han behövde dem strax. Jag kunde naturligtvis icke säga nej, och då jag icke för tillfället hade någon att skicka, måste jag gå själv. Jag gick alltså - och på hemvägen, just utanför min port, träffade jag en annan av mina vänner, som var sysselsatt med att fara omkring $i$ en droska och bilda ett bolag och som frågade mig om jag hade lust att övertaga posten som kassadirektör. Jag ville icke säga nej så där utan vidare, det hade ju sett ovänligt ut; jag gick därför att börja med in på att äta frukost med honom för att resonera vidare om saken. Först åto vi frukost alltså, och därefter började vi resonera. Klockan hade blivit två på dagen, och vi voro just nära att komma till ett definitivt resultat, då min jungfru, som på något outrannsakligt sätt hade fått spaning på min vistelseort, kom inrusande och 
berättade, att min svärmor låg för döden. Men svärmor bor på Kungsholmen; jag tog alltså en droska och körde dit. Mycket riktigt, min svärmor låg verkligen för döden; men hon dog inte förrän vid sextiden. Äntligen kunde jag alltså få komma hem och skriva färdigt min roman... Men se; på Jakobs torg stannade jag som vanligt utanför Silvanders för att se på ett nytt slags handskar, och då jag vände mig om för att fortsätta hemåt, stod jag ansikte mot ansikte med en tredje av mina vänner, en man som var trött på att bilda bolag och hellre ville spela schack. Han frågade mig alltså om jag ville dricka whisky och spela schack. - Tacka tusan för det, svarade jag utan betänkande, ty jag hade helt och hållet glömt bort min roman, och då jag i nästa ögonblick erinrade mig den på nytt, hade jag ju redan sagt ja och kunde icke ändra mig - det skulle ha gjort ett karaktärslöst intryck. Alltså följdes vi åt hem till honom och drucko whisky och spelade schack till klockan elva. Då sade jag god natt och gick hem med den orubbliga föresatsen att skriva färdigt min roman - och nu börjar historien.

Hör nu på:

Jag hade ungefär tio minuters väg hem. Då jag hade gått halva vägen märkte jag att jag var trött och en smula sömnig och gjorde ofrivilligt den reflexionen, att det förmodligen inte skulle gå bra att skriva, om jag gick hem och satte mig vid skrivbordet sådan jag var.

- Här till höger ligger en trevlig kaférestaurang, sade jag till mig själv. Om jag går in där och dricker en stor kopp full med starkt te och sedan går hem och skriver, kommer slutkapitlet i min roman att bli storartat.

Jag gick alltså in.

I kaféet satt svenska folket som vanligt och drack punsch.

Ett enda litet bord var ledigt, och det stod mitt i salen. Där slog jag mig ned.

- Får jag en kopp te, sade jag till en av uppasserskorna.

Det blev alldeles tyst i salen. Runtomkring satt svenska folket med tjocka magar och rosiga kinder och drack punsch; och med regelbundna mellanrum stötte de glasen tillsammans och sade: nu tar vi en bottenfock!

Men då jag begärde en kopp te, blev det alldeles tyst i rummet.

- En kopp te? frågade uppasserskan med ett osäkert tonfall.

- Ja, svarade jag, en kopp te!

- Skall det bara vara te? Skall det inte vara smör och bröd? Och brännvin och öl? Och punsch?

- Nej tack, svarade jag vänligt. Jag vill bara ha en kopp te. 
- Det skall bli, svarade uppasserskan.

Man stirrade på mig från alla håll. På en hel minut var det ingen, som tog en bottenfock.

Man talade om mig runtomkring, och jag hörde en del av vad som sades.

- Det är en tokig utlänning, sade en.

- Fy fan, så mycket hyckleri och skoj det finns nu för tiden, sade en annan.

- Han är full och vill bli nykter, sade en tredje.

- Hur kan man vilja bli nykter, när man är full, sade en fjärde.

Uppasserskan kom med mitt te. Jag betalade strax och gav henne en krona i drickspengar för att hon inte skulle tro, att jag drack te därför att jag icke hade råd att dricka punsch.

Men jag kom aldrig i tillfälle att dricka ur detta te. Jag satt helt tyst och fredligt och rörde i det och försökte genom hela mitt uppförande göra klart för mina grannar, att jag icke ville dem något ont - då en gammal uppsalakamrat, som jag icke hade sett på femton år, med ens stod framför mig och stirrade med stela ögon på mig och min tekopp. smörjan?

- Är det verkligen du? sade han upprörd. Och du tänker dricka den där

- Ja, svarade jag blygt.

- Jaså, dit har det alltså gått med dig till sist. Det var ruskigt!

Jag trodde att han skämtade och försökte svara något i samma ton.

- Jag tror du försöker göra dig kvick, svarade min gamle kamrat.

Och nu först märkte jag, att han var full som en katt.

Utan omsvep anförtrodde han mig därefter, att han ända från första stunden av vår bekantskap aldrig kunnat tåla mig. Han hade strax insett att jag var en humbug, eller, om jag ville att han skulle uttrycka sig tydligare, en fähund. Han hade alltid längtat efter ett passande tillfälle att få säga mig det, och nu var det sagt!

Min gamle kamrat hade talat upp sig mer och mer; till slut skrek han så det hördes över hela salen. Alla lyssnade förtjusta, och källarmästaren kom fram i dörren. Det var en stor, rödbrusig karl.

- Vad är det fråga om? sade han med ett visst hot i rösten och såg sig omkring i församlingen.

Då pekade alla på mig och sade i korus:

- Det är den där herrn, som sitter och är oförskämd! 
Uma xícara de chá

Dizem que na Inglaterra quem bebe aguardente ou outras bebidas similares em público arrisca boa parte do prestígio social. Mas o nosso país tem outros costumes. Ontem me dei um tanto mal quando resolvi beber uma xícara de chá no café... ah, pouco importa em que café!

A questão é que estou dando os últimos retoques em um romance em duas partes, no qual pretendo denunciar a falsidade de toda a vida social moderna. Falta apenas o último capítulo, e eu tinha me decidido a escrevê-lo ontem. Levantei-me, portanto, às oito da manhã, sentei-me à escrivaninha tomado pela febre de um poeta, trajando apenas uma camisa, e comecei: "O entardecer de outubro estendia-se cada vez mais denso acima da cidade, enquanto a chuva de outono...". Mais não pude escrever, pois nesse instante o telefone tocou. Era um dos meus amigos, que queria tomar dinheiro emprestado - a bagatela de umas poucas centenas de coroas, mas ele precisava da quantia o mais depressa possível. Naturalmente eu não podia recusar, e como naquele momento eu não tinha ninguém que pudesse fazer a entrega para mim, precisei ir eu mesmo. Então fui -e no caminho de volta para casa, bem em frente à minha porta, encontrei um outro amigo meu, que se ocupava em andar de um lado para o outro de coche e em constituir uma sociedade e que me perguntou se eu não estaria disposto a assumir o cargo de tesoureiro. Eu não quis recusar o convite logo de cara - seria muito inamistoso; assim, para começar, fui tomar café da manhã com ele para discutir melhor o assunto. Primeiro tomamos o café da manhã e depois começamos a discutir. Já eram duas da tarde e estávamos prestes a chegar a um resultado definitivo quando a minha criada, que de maneira inexplicável havia se inteirado a respeito de meu paradeiro, entrou correndo e disse que a minha sogra estava à beira da morte. Porém a minha sogra mora em Kungsholmen; então tomei um coche e fui até lá. Muito bem, de fato a minha sogra estava à beira da morte; mas ela não morreu antes das seis horas. Depois pude finalmente ir para casa terminar de escrever o meu romance... Mas eis que no Jakobs Torg parei como de costume em frente à loja de Silvander para examinar um novo tipo de luva e, quando me virei para retomar o caminho de casa, fiquei cara a cara com um terceiro amigo meu, um homem que estava farto de constituir sociedades e preferia jogar xadrez. Logo ele me perguntou se eu não gostaria de beber uísque e jogar xadrez. Mas é claro, respondi sem pensar, pois eu tinha me esquecido completamente do meu romance, e quando no instante seguinte tornei a lembrar, eu já tinha aceitado o convite e não podia mudar de ideia - isso daria a impressão de falta de caráter. Então seguimos até a casa dele e bebemos uísque e jogamos xadrez até as onze 
horas. Por fim desejei boa noite e fui para casa determinado a terminar de escrever o meu romance - e agora começa a história.

Preste atenção:

Até a minha casa era uma caminhada de cerca de dez minutos. Quando eu havia percorrido a metade do caminho percebi que eu estava cansado e um pouco sonolento e fiz a reflexão involuntária de que provavelmente não seria bom escrever se eu fosse para casa e me sentasse à escrivaninha no estado em que eu me encontrava.

- Conheço um café e restaurante muito agradável logo aqui à direita disse eu para mim mesmo. - Se eu for até lá agora e beber uma xícara grande de chá bem forte e depois for para casa escrever, o último capítulo do meu romance vai ser magistral.

Então fui até lá.

No café, como de costume, havia suecos que bebiam ponche.

Uma única mesinha estava desocupada, no meio do salão. Fui até lá e me deixei cair em cima da cadeira.

- Uma xícara de chá - disse eu a uma das garçonetes.

Fez-se silêncio no salão. Ao meu redor estavam suecos com barrigas gordas e bochechas coradas que bebiam ponche e a intervalos regulares faziam brindes e diziam: vira, vira, vira!

Mas quando eu pedi uma xícara de chá, tudo ficou em silêncio.

- Uma xícara de chá? - perguntou a garçonete com uma nota de insegurança na voz.

- É - disse eu -, uma xícara de chá!

- Só uma xícara de chá? O senhor não quer um pão com manteiga? E aguardente ou cerveja? Ou ponche?

- Não, obrigado - respondi. - Quero apenas uma xícara de chá.

- Pois não - respondeu a garçonete.

Todos os olhares voltaram-se na minha direção. Por um minuto inteiro ninguém tomou um gole sequer.

Ao meu redor começaram a falar sobre mim, e eu consegui ouvir parte dos comentários.

- É um estrangeiro louco - disse alguém.

-É uma vergonha a hipocrisia e a pilantragem que existem hoje em dia disse um outro. 
- Ele está bêbado e quer ficar sóbrio - disse um terceiro.

- Como pode alguém querer ficar sóbrio estando bêbado? - disse um quarto.

A garçonete chegou com o meu chá. Paguei no mesmo instante e dei-lhe uma coroa de gorjeta, para que soubesse que eu não havia pedido chá por não ter condições de beber ponche.

Mesmo assim, não tive oportunidade para beber do chá. Permaneci calado e tranquilo enquanto mexia a colher, e através da minha postura, tentei deixar claro a todos os presentes que eu não lhes desejava mal nenhum - quando um velho camarada de Uppsala que eu não via há quinze anos surgiu na minha frente, encarando com um olhar severo o meu rosto e a minha xícara de chá.

- É você mesmo? - perguntou, tomado de agitação. - E você vai tomar essa porcaria?

- Vou - respondi, tímido.

- Muito bem, então foi assim que você acabou. Que horror!

Achei que se tratava de uma brincadeira e tentei responder no mesmo tom.

- Parece que você está querendo se passar por esperto - respondeu o meu velho camarada.

Nesse instante percebi que ele estava bêbado como um gambá.

Sem nenhum rodeio ele confessou a seguir que desde o primeiro momento de nossa convivência tinha me achado uma pessoa insuportável. Assim que nos conhecemos havia percebido que eu era um farsante, ou, se eu quisesse que se exprimisse em termos mais precisos, que eu era um patife. Sempre havia esperado pela oportunidade de me dizer isso, e o momento enfim havia chegado!

Meu velho camarada começou a vociferar cada vez mais alto; no fim os gritos ecoavam pelo salão inteiro. Todos o escutavam tomados de encanto, e por fim o dono do restaurante apareceu na porta. Era um homem grande e de rosto vermelho.

- Qual é o problema? - perguntou com um certo tom de ameaça na voz antes de olhar para a companhia ao redor.

Então todos apontaram para mim e disseram em coro:

- É aquele senhor ali, que não tem vergonha na cara! 